\title{
Studentų požiūris ị studijas VU meteorologijos ir hidrologijos bakalauro studijų programoje (2014-2016 m. tyrimas)
}

\author{
Gintaras Valiuškevičius \\ Vilniaus universitetas, \\ Čiurlionio g. 21, LT-03101 Vilnius \\ El.paštas gintaras.valiuskevicius@gf.vu.lt
}

\begin{abstract}
Valiuškevičius G. Studentų požiūris ị studijas VU meteorologijos ir hidrologijos bakalauro studiju programoje (2014-2016 m. tyrimas). Geologija. Geografija. 2017. T. 3(1). ISSN 2351-7549.

Studentų požiūris ị savo pasirinktą studijų programą - svarbus rodiklis, lemiantis studijų rezultatus, leidžiantis parinkti tinkamiausią studijų organizavimo metodiką ir programos struktūrą. Siekiant išsiaiškinti VU meteorologijos ir hidrologijos bakalauro studiju programos studentu nuomonę apie studijas, 2014-2016 m. buvo organizuota anoniminè 1 ir 4 kurso studentų apklausa. Apklausos rezultatų apibendrinimas rodo, kad daugeliu klausimų šios studijų programos studentų nuomonè panaši i daugumos Lietuvos aukštujjų mokyklų bakalaurantų požiūrị, išryškẻjusi visoje šalyje vykdytų apklausų metu. Iš atsakymų i anketos klausimus galima spręsti, kad studijuojantieji meteorologiją ir hidrologiją labiausiai tikisi gauti daugiau profesinių žinių. Duomenys rodo, kad 1 kurso studentai pozityviau nusiteikę pasirinktos studijų programos atžvilgiu nei 4 kurso studentai.
\end{abstract}

Raktažodžiai: aukštasis mokslas, meteorologija ir hidrologija, Vilniaus universitetas, studentų apklausa, požiūris ị studijas

\section{IVADAS}

Studentų nuomonė apie studijas - itin svarbus rodiklis, $\mathfrak{i}$ kurị būtina atsižvelgti planuojant studijų programų struktūrą ir dèstymo metodus. Siekiant ją išsiaiškinti, dažniausiai organizuojamos ìvairaus pobūdžio anoniminès apklausos. Vilniaus universitete tokius tyrimus nuolat organizuoja Strateginio planavimo ir kokybès skyrius (buvęs Kokybès vadybos centras). Deja, išsamūs šių apklausų rezultatai pasiekiami tik vidiniame universiteto tinklalapyje (Vilniaus universitetas..., 2017), o viešai prieinama informacija - pernelyg abstrakti, kad leistų spręsti apie konkrečią stu- dijų programą pasirinkusių studentų nuomonę. Susidaryti kiek išsamesni vaizdą apie studentų požiūrị i studijų programos turinị ir jo igyvendinimą šiuo metu gali tik kamieninių ar šakinių padalinių vadovai ir studijų programų komitetų pirmininkai, tačiau jie taip pat mato tik atsiliepimus apie konkrečius dèstomus dalykus. Negana to, neturint galimybės šių rezultatų viešinti, dažnai nelieka ir motyvų užsiimti platesne duomenų analize.

Déstytojai VU informacineje sistemoje mato tik studentų atsiliepimus apie jų dèstomus dalykus, todèl pasigenda informacijos apie bendrą studijų programos vertinimą. Susidaryti objektyvią 
nuomonę apie studentų požiūrị ì programos ar konkretaus dalyko privalumus, trūkumus trukdo ir menkas studentų aktyvumas pildant anoniminių apklausų anketas. Jų pildymas nèra privalomas, todèl dauguma atvejų $\mathfrak{i}$ klausimus atsako nuo kelių iki keliasdešimties procentų paskaitas lankiusių studentų (asmeninè autoriaus patirtis rodo, kad nuo 2011 m., dèstant 4 skirtingus dalykus, ị klausimus apie juos nè karto neatsakè daugiau nei pusė klausytojų).

Šios priežastys paskatino imtis atskiro tyrimo ir méginti išsiaiškinti, ką studentai mano apie pasirinktą studijų programą. Apklausos pradètos vykdyti $2014 \mathrm{~m}$. ir buvo atliekamos kaskart baigiant dèstyti vieno ar kito dalyko kursą. Šiuo metu turimi duomenys už trejus mokslo metus, tad rezultatai dar neleidžia atlikti išsamios statistinès analizès. Tačiau esminių tendencijų apžvalgai ir pradiniams apibendrinimams šio informacijos kiekio pakanka.

Straipsnio tikslas - atskleisti svarbiausius studentų motyvus renkantis ir studijuojant meteorologijos ir hidrologijos bakalauro studijų programą. Taip pat méginama apibūdinti studijuojančiųjų šioje programoje požiūrio ì programos struktūrą, turinị, dèstymo kokybę bei studijų tvarkaraštị kaitą ir išryškinti galimai ją lemiančius veiksnius. Dèl duomenų stokos tyrimas nepretenduoja ị išsamią analizę, tačiau gali padèti mèginant suvokti esamą situaciją ir koreguojant studijų programos struktūrą bei dėstytojų santykių su studentais modeli. Analizès rezultatai gali praversti ir vertinant bendrą VU studijų programų (ypač geomokslų srityje) kokybę, nustatant esmines joms būtinų pokyčių gaires bei parenkant tinkamiausią edukacinę paradigmą. Skelbiama medžiaga turètų sudominti ir studentus, kurie pasigenda apibendrintų duomenų apie bendramokslių požiūrị i studijas.

\section{STUDENTŲ NUOMONĖS TYRIMŲ RAIDA LIETUVOJE}

Pirmieji studentų nuomonès vertinimai kai kuriose šalyse pradèti vykdyti nuo $\mathrm{XX}$ a. vidurio ir devintojo šio amžiaus dešimtmečio pabaigoje tapo sudètine bendros aukštojo mokslo ir studijų vertinimo sistemos dalimi (Savickienè, $\mathrm{Pu}-$ kelis, 2004). Lietuvoje tokio pobūdžio apklausos pradètos rengti maždaug prieš du dešimtmečius.
Pradžioje šiuos tyrimus vykdè pavieniai mokslininkai, analizavę grịžtamojo ryšio problemas aukštosiose mokyklose, vèliau periodiškai vykdomų apklausų duomenis pradèjo kaupti atskiri universitetai. Tačiau maždaug vieninga tyrimų struktūra nusistovèjo tik XXI a. pradžioje, kai studentų atsiliepimus savo analizei èmé naudoti centrinès šalies mokslo ir studijų sistemos kokybę prižiūrinčios ìstaigos: Mokslo ir studijų stebèsenos ir analizès centras (MOSTA) ir Studiju kokybès vertinimo centras (SKVC).

Pirmuosius studentų požiūrio ì studijas apibendrinimus Lietuvos mokslineje spaudoje paskelbė VU ir VDU tyrèjai. Dalis jų (Kanopienè, Tureikytè, 2001; 2002) labiau kreipè demesi $\mathfrak{i}$ bendruosius sociologinius dèsningumus, mėgindami atsekti studentu požiūrio ì mokymąsi priklausomybę nuo studijuojančiųjų pasiskirstymo pagal amžių, lyti ar gyvenimo sąlygas. Kiti (Savickiené, Pukelis, 2004; Valiuškevičiūtè ir kt., 2004) dažniau akcentavo edukacinio modelio funkcionavimo problemas, pabrěždami studiju proceso dalyvių ir jo organizatorių tarpusavio santykius atspindinčius aspektus. Nors pirmosios apklausos buvo vykdomos vos keliuose universitetuose (dažnai kiekviename iš jų taikant skirtingas metodikas) ir kai kurie jų rezultatai šiuo metu mažai aktualūs (tarp kitų klausimų, pirmosiose apklausų anketose studentų buvo teiraujamasi, ar jie naudojasi internetu, elektroniniu paštu ir pan.), jos padejo susiformuoti bendrai apklausu sistemai - šiuo atžvilgiu ypač svarbūs I. Savickienès ir bendraautorių (Savickienė, Pukelis, 2004; Savickienè, 2005) darbai - ir paskatino platesnius šios srities tyrimus. Pirmosiose studijose skelbtu duomenų palyginimas su dabartiniais apklausu rodikliais leidžia suvokti, kurios studijuojančių jaunuolių nuostatos labiau priklauso nuo momentinių aplinkybių (nors ị universitetus jau atejo nauja studentų karta, atsakymai į kai kurias klausimų grupes, pavyzdžiui, apie stojimo motyvaciją, per keliolika metų mažai pakito).

Beveik tuo pačiu metu pasirodè darbų, kuriuose nagrinèta ne tik studentur, bet ir moksleivių, absolventų, dèstytojų, darbdavių bei kitų studijų kokybe suinteresuotų grupių nuomonè. Absolventų požiūrị i t studijų kokybę išsamiai aptarè B. Čèsnaité (2002), dèstytojų ir administracijos - D. Lepaite (2003). Studentų nuomonès svarbą, kintant aukštojo mokslo paradigmai 
Lietuvoje, nagrinejjo D. Gudaitytè ir P. Jucevičienè (2000). Po kelių metu sociologai savo tyrimuose èmé analizuoti studentų apklausų rezultatų sąsajas su jų ìsidarbinimo galimybèmis (Rosinaité, 2008). Kartu imta domètis studentų požiūriu ì studijų apimtị, galimybėmis koreguoti studijų tvarkaraštị bei programos struktūrą (Sirtautienè, 2006).

Visa tai leido suformuoti vieningą studentų požiūrio ì studijas vertinimo schemą, kurią nuo XXI a. antrojo dešimtmečio, koordinuojami MOSTA, emé taikyti visi Lietuvos universitetai. Šiuo metu sukaupti duomenys leidžia ne tik parengti įvairiapuses ataskaitas apie studijuojančiųjų nuomonę ir ją lemiančius veiksnius (MOSTA, 2014; 2017), bet ir nagrinèti studentu pažiūras filosofiniu rakursu (Tijūnèlienè, 2012), specifikuoti studentu nuomonę pagal prioritetinius lūkesčius, mokymosi patirtị (Pruskus ir kt., 2015), ieškoti analizès rezultatų pritaikymo universitetų dèstytojų veiklai optimizuoti (Jezerskytè, Janiūnaitè, 2010).

Kol kas Lietuvoje pasigendama konkrečias studiju programas pasirinkusių studentų nuomonès apie studijų aplinką apibendrinimų. Dauguma darbų skirti bendram visos šalies arba tam tikro universiteto (kartais kelių universitetų) studentų pozicijos vertinimui, kas dažnai trukdo i̊sivaizduoti skirtingas specialybes studijuojančių respondentų pažiūrų ịvairovę ir jų priklausomybę nuo programų specifikos.

\section{DUOMENYS IR METODIKA}

Tyrimas paremtas 2014-2016 m. autoriaus atliktų anoniminių studentų apklausų duomenimis. Jų metu studentams, klausiusiems „Hidrologijos pagrindu“ ir "Taikomosios hidrologijos“ kursus, buvo dalinamos anketos su klausimais apie pasirinktą studijų programą ir išklausytą dalyką. Apklausų organizavimo sistema, grafikas ir dalyviai apibūdinti 1 lentelèje. Tyrimo metu apklausti 133 studentai (40 Meteorologijos ir hidrologijos studiju programos pirmajame semestre, 29 - septintajame semestre; 64 - Geografijos studijų programos pirmajame semestre).

Pagrindinis apklausų tikslas buvo išsiaiškinti studentų nuomonę apie konkretų dèstomą dalyką ir jo dèstymo ypatumus, todèl anketos buvo pateikiamos semestro pabaigoje, per paskutinę dalyko paskaitą. "Hidrologijos pagrindai“ destyti ne tik meteorologijos ir hidrologijos, bet ir ekologijos bei geografijos bakalauro studiju programų studentams, tačiau galimybès išsamiau panagrinèti besimokančiųu požiūrị ì pasirinktą studijų programą buvo tik meteorologijos ir hidrologijos studijų programoje. Šią specialybę pasirinkusių studentų apklausos

1 lentelè. Anoniminès studentų apklausos, kurių rezultatai panaudoti tyrime

Table 1. The anonymous surveys of students whose results were used in the research

\begin{tabular}{|c|c|c|c|c|}
\hline $\begin{array}{c}\text { Dalykas, kuri } \\
\text { dėstant vykdyta } \\
\text { apklausa } \\
\text { Course during } \\
\text { which survey } \\
\text { was conducted }\end{array}$ & $\begin{array}{l}\text { Data } \\
\text { Date }\end{array}$ & $\begin{array}{l}\text { Studiju programa } \\
\text { Study programme }\end{array}$ & 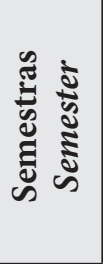 & 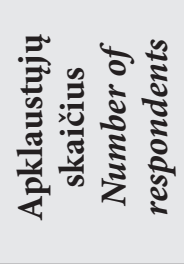 \\
\hline \multirow{6}{*}{$\begin{array}{l}\text { Hidrologijos } \\
\text { pagrindai } \\
\text { Fundamentals } \\
\text { of hydrology }\end{array}$} & \multirow{2}{*}{20141216} & Meteorologija ir hidrologija / Meteorology and hydrology & 1 & 13 \\
\hline & & Geografija / Geography & 1 & 25 \\
\hline & \multirow{2}{*}{20151222} & Meteorologija ir hidrologija / Meteorology and hydrology & 1 & 12 \\
\hline & & Geografija / Geography & 1 & 18 \\
\hline & \multirow{2}{*}{20161220} & Meteorologija ir hidrologija / Meteorology and hydrology & 1 & 15 \\
\hline & & Geografija / Geography & 1 & 21 \\
\hline \multirow{3}{*}{$\begin{array}{c}\text { Taikomoji } \\
\text { hidrologija } \\
\text { Applied } \\
\text { hydrology }\end{array}$} & 20141219 & Meteorologija ir hidrologija / Meteorology and hydrology & 7 & 10 \\
\hline & 20151218 & Meteorologija ir hidrologija / Meteorology and hydrology & 7 & 12 \\
\hline & 20161223 & Meteorologija ir hidrologija / Meteorology and hydrology & 7 & 7 \\
\hline
\end{tabular}


vykdytos ịvairiais semestrais, kas leido išryškinti apklaustujų nuomonès kaitą studijų pradžioje (baigiantis pirmajam semestrui) ir pabaigoje (baigiantis priešpaskutiniam semestrui). Geografijos studijų programos studentų apklausų rezultatai tyrime naudoti tik palyginimui, siekiant atskleisti skirtingų studijų programų klausytojų skirtumus to paties studijų etapo metu (prieš pirmos sesijos pradžią). Ekologijos studijų programos studentų apklausuc rezultatai tyrime nenaudoti, nes jie tą pati dalyką klauso 3 kurse (penktajame semestre), todèl atsakymai išsiskiria ne tik dèl mokslų krypties, bet ir dèl amžiaus bei mokymosi patirties skirtumų.

Tyrimui panaudoti anketos klausimai apie studentų požiūrị ị savo studijų programą, neanalizuojant jų nuomonès apie konkretų dèstomą dalyką (tam buvo skirta atskira anketos dalis). Studiju programai apibūdinti buvo skirta 11 klausimų, ì kuriuos raštu atsakantiems respondentams buvo siūloma rinktis vieną iš kelių galimų atsakymų variantų (2 lentelè). Nesant galimybès apsiriboti konkrečių atsakymo variantų pateikimu, atsakant i kai kuriuos klausimus studentams leista rinktis atsakymą „kita“ ir įrašyti jų nuomone tinkamiausią atsakymą (galimybe išsakyti atskirą nuomonę, nesutampančią su testo formato atsakymais klausimyne, naudotasi santykinai retai, dažniausiai

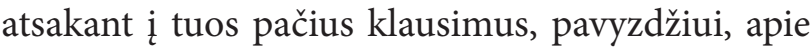
studijų metu labiausiai nuvylusius dalykus). Esant nedideliam studentų skaičiui grupèse ir siekiant užtikrinti apklausos dalyvių anonimiškumo garantijas, nebuvo pateikti klausimai apie amžių, lyti ir gimimo vietą. Apklaustieji privalèjo nurodyti tik savo studiju programos pavadinimą. Sudarant klausimyną buvo atsižvelgta $\mathfrak{i}$ tai, kokie klausimai studentams pateikiami bendrujų universiteto apklausų metu (visiškai identiškų klausimų, apie kuriuos galima susidaryti nuomonę iš bendru tyrimų, stengtasi nepateikti). Keletas klausimų, kurie buvo pateikti pirmą kartą vykdant apklausą, vèliau nebebuvo ittraukiami it klausimyną (ir nenaudoti šiame tyrime), nes paaiškejo, kad studentams sudètinga juos suvokti arba buvo neinformatyvūs.

2 lentelè. Apklausų metu pateikti klausimai (pilkai pažymėtos atsakymų grupès laikytos alternatyviomis pagrindiniam atsakymo variantui)

Table 2. Survey questions (gray-marked answers group were regarded as alternative to the main answer version)

\begin{tabular}{|c|c|}
\hline Klausimas / Question & Atsakymų variantai / Answer versions \\
\hline & 1. Ji man labai patiko / I liked it. \\
\hline $\begin{array}{l}\text { Stodamas ị VU pasirinkau šią studijų } \\
\text { programą nes: } \\
\text { When trying to get into university I chose this } \\
\text { study programme because: }\end{array}$ & $\begin{array}{l}\text { 2. Čia buvo lengva ịstoti / It was easy to get into. } \\
\text { 3. Šioje srityje geros įsidarbinimo ir karjeros galimybès / This } \\
\text { area is good for employment and career opportunities. } \\
\text { 4. Tikèjausi, kad ją baigęs galèsiu daug uždirbti / I hoped that } \\
\text { after graduation I can earn very much. } \\
\text { 5. Kita (galite įrašyti) / Other (specify). }\end{array}$ \\
\hline
\end{tabular}

Pateikdamas studijų prašymą LAMA BPO

1. Pirmu numeriu / First position.

sistemoje šią studijų programą pažymėjau:

When writing an application to LAMA BPO

2. Antru arba trečiu numeriu / Second or third position.

system, I marked this study programme as:

3. Žemesniu numeriu / Further position.

1. Internete / In the Internet.

2. Iš pažįstamų / From friends.

Apie šią studijų programą sužinojau:

3. Iš anksčiau čia besimokiusių žmonių / From people who studied here earlier.

I have learned about this study programme:

4. Per studijų mugę arba atvirų durų dieną / During study fair or open day.

5. Kita (galite įrašyti) / Other (specify).

Stodamas tikejjausi, kad mokytis šioje studijų programoje bus:

When entering I expected that studies in this

study programme will be:

1. Sunkiau / More difficult.

2. Lengviau / Easier.

3. Tikejjausi, kad panašiai ir bus / I expected similar. 
2 lentelè. (tęsinys)

Table 2. (continued)

\begin{tabular}{c|c}
\hline $\begin{array}{c}\text { Klausimas } \\
\text { Question }\end{array}$ & Atsakymų variantai \\
Answer versions
\end{tabular}

Pasimokęs pasirinktoje studijų programoje galiu teigti, kad:

After studying in this study programmme I can say that:
1. Patekau ten, kur tikejjausi / I got where I expected.

2. Patekau ne ten, kur tikejjausi / I did not get where I expected.

3. Nežinau, ar teisingai pasirinkau / I do not know if my choice. was correct.

4. Kita (galite įrašyti) / Other (specify).
Šiuo metu manau, kad mano pasirinktos studijų programos bendras lygis (palyginti su kitomis) yra:

At this time I believe that the level of this study programmme (in comparison with others) is:

Manau, kad šią bakalauro studijų programą derètų sutrumpinti:

I think that this bachelor's degree programme should be shortened:

Mokymosi šioje studijų programoje metu labiausiai nusivyliau:

By learning in this study programme I was most disappointed with:
1. Aukštas / High.

2. Vidutinis / Average.

3. Žemas / Low.

1. Iki 3 metų / Up to 3 years.

2. Iki 3,5 metų / Up to 3.5 years.

3. Nemanau, kad ją reikia trumpinti / I do not think that it needs to be shortened.

1. Studijų programos struktūra (tikèjausi, kad bus dèstomi kiti dalykai) / The structure of study programme.

2. Déstymo kokybe / The quality of teaching.

3. Bendramoksliais / Fellow students.

4. Studijų tvarka ir tvarkaraščiu / The arrangements of studies and timetable.

5. Kita (galite ịrašyti) / Other (specify).

1. Žinočiau, kad po studijų baigimo dirbsiu pagal profesiją / I knew that after graduation I will work according to professional qualification.

Šiuo metu mano noras mokytis labiausiai padidètu jeigu:

At this time my desire to study would mostly increase if:

2. Geri mokymosi rezultatai būtų skatinami didelèmis stipendijomis / Good performance were motivated with large scholarships. 3. Paskaitos būtų idomesnès / Lectures were more interesting. 4. Kita (galite įrašyti) / Other (specify).

Man palankiausias studijų tvarkaraščio variantas būtų jeigu:

The most favourable study schedule for me would be if:

1. Dauguma paskaitų vyktų antroje dienos pusejje / Most of the lectures took place in the second half of the day.

2. Dauguma paskaitu vyktu pirmoje dienos puseje / Most of the lectures took place in the first half of the day.

3. Paskaitos truktų ilgesnị laiką, bet vyktų ne visomis darbo dienomis / Lectures were longer but not in all working days.

1. Būtų daugiau specialybès dalykų / If there were more specialty disciplines.

Manau, kad studijų programos turinys pagerètu jeigu joje:

I think that the study programme would improve if:
2. Būtų daugiau bendrųjų fizinių-gamtamokslinių dalykų / There were more general physical-natural science subjects.

3. Būtų daugiau bendrujų socialinių humanitarinių dalykų / There were more general social-humanities subjects.

4. Kita (galite įrašyti) / Other (specify). 
Anketos pabaigoje studentų buvo prašoma išsakyti nuomonę apie ją ir pasakyti, kokių klausimų jie pasigedo. Kadangi tyrimas vis dar tęsiamas, atsižvelgiant $\mathfrak{i}$ šiuos pasiūlymus ateityje tikimasi pakoreguoti klausimyno struktūrą.

Apdorojant duomenis buvo naudojamasi „Excel“ skaičiuokle, kiekvienas atitinkamo atsakymo varianto pasirinkimas žymètas 1 , o nepasirinkimas 0 . Tai leido įvertinti kokybinius rodiklius taikant kiekybiniams rodikliams tinkamą apdorojimo schemą. Méginant nustatyti studentų nuomonės pokyti nuo pirmojo iki septintojo semestro, buvo įvertinta ir palyginta ivairius atsakymų variantus pasirinkusių respondentų dalis (\%). Nedidelis apklaustųjų skaičius ir trumpas tyrimo laikotarpis neleido įvertinti tos pačios studentų grupès nuomonès kaitos metai iš metų, todèl palyginimui naudoti bendri per trejus metus vykdytų apklausų rezultatai (atskirai vertinant nuomonès pasiskirstymą pirmojo ir septintojo semestro metu). Esant santykinai nedidelei duomenų imčiai, tam tikri skirtumai tarp pirmojo ir septintojo semestro vykdytų apklausų rezultatu gali būti nulemti ir specifinių aplinkybių (duomenų reprezentatyvumą papildomai iškreipia tai, kad i anketose pateiktus klausimus atsakinejo tik aktyviai paskaitas lankę studentai; be to, tuo pačiu metu organizuojant 1 ir 4 kurso studentu apklausas atsakymai skiriasi ne tik dèl respondentų mokymosi patirties, bet ir dèl jų išankstinio pasirengimo studijoms, motyvacijos, amžiaus skirtumo).

Taip pat siekta išsiaiškinti, ar studentų nuomonè tam tikru klausimu susijusi su jų požiūrio $\mathfrak{i}$ kitus klausimus ypatumais. Tuo tikslu nustatyta, kokia dalis respondentų rinkosi identiškus atsakymus i skirtingus klausimus. Kadangi bendras apklaustụjų skaičius nebuvo didelis, skaičiuojant ši rodiklį atsakymų ị kai kuriuos klausimus variantai buvo sugrupuoti pasirenkant visą atsakymo variantų grupę kaip alternatyvą dažniausiai pasirenkamam atsakymo variantui (alternatyvių atsakymų grupès 2 lentelèje pažymètos pilkai). Tais atvejais, kai atsakymų variantų negalima buvo laikyti alternatyviais, nagrinètos sąsajos tarp kelių skirtingų atvejų skaičiuojant identiškų pasirinkimų dali kiekvienam atvejui atskirai.

\section{TYRIMO REZULTATAI}

Apibūdindami stojimo ir mokymosi motyvus bei sąlygas meteorologijos ir hidrologijos studijų programos studentai dauguma klausimų turèjo pakankamai vieningą nuomonę. Tai ypač būdinga pirmakursiams - daugiau nei $50 \%$ apklaustujuc rinkosi tą patį atsakymo variantą atsakydami i 10 klausimų (iš 11). Vienintelis klausimas, atsakydami ị kurị daugiau nei pusè 1 kurso studentų neturèjo vieningo požiūrio, buvo apie mokymosi sudètingumą (Stojant tikejjausi, kad mokytis šioje studiju programoje bus: 1) sunkiau (10,0 \%), 2) lengviau (42,5 \%), 3) panašiai (47,5\%)).

Vienareikšmè pozicija studentams pirmojo semestro pabaigoje buvo labiausiai būdinga atsakant í klausimus apie programos pasirinkimo aplinkybes: 80,0 \% respondentų pasirinko šią studijų programą, nes ji labai patiko; 73,2 \% apie ją sužinojo internete; $67,5 \%$ - pildydami prašymus bendro prièmimo organizavimo sistemoje (LAMA BPO) pažymejjo ją pirmu numeriu. Daugiau nei du trečdaliai pirmakursių pirmojo semestro pabaigoje mano galintys teigti, kad „pateko ten, kur tikèjosi“" (1 pav., a). Pabrèžtina, kad geografijos studijų programos studentai pirmojo semestro pabaigoje taip pat išreiškè panašų požiūrị ì programos pasirinkimo aplinkybes. 74,2 \% jų rinkosi šią programą todèl, kad ji labai patiko; $75,0 \%$ stodami žymèjo ją pirmu numeriu; $67,2 \%$ manè, kad pateko ten, kur ir tikejosi. Tarp studijuojančiųjų geografiją kiek mažesnis apie šią studijų programą internete sužinojusiųjų procentas $(64,6 \%)$, kas galimai sietina su tuo, jog geografija, skirtingai nei meteorologija ir hidrologija, yra vidurinèje mokykloje dèstomas dalykas. Visais šiais klausimais meteorologijos ir hidrologijos bei geografijos 1 kurso studentų nuomonès labai panašios $\mathfrak{i}$ bendras Lietuvos tendencijas, išryškẻjusias apklausiant aukštųjų mokyklų bakalaurantus (MOSTA, 2014).

4 kurso meteorologu ir hidrologų nuomone šiais klausimais taip pat panaši (dauguma atsakiusiųjų dažniausiai rinkosi tuos pačius atsakymų variantus kaip ir pirmakursiai). Net 75,9 \% ketvirtakursių sužinojo apie pasirinktą studijų programą internete, o 72,4 \% ši pasirinkimą LAMA BPO žymèjo pirmu numeriu. Kiek ryškiau skyrèsi 4 kurso studentų atsakymai į klausimus apie studiju programos pasirinkimo motyvus ir savo vietos joje suvokimą. Lyginant su 1 kurso studentais, žymiai mažesnẻ baigiančiųjų bakalauro studijas dalis (46,9\%) nurodè, kad rinkosi programą dèl to, jog ji labai patiko. Tai galejo lemti gerokai 


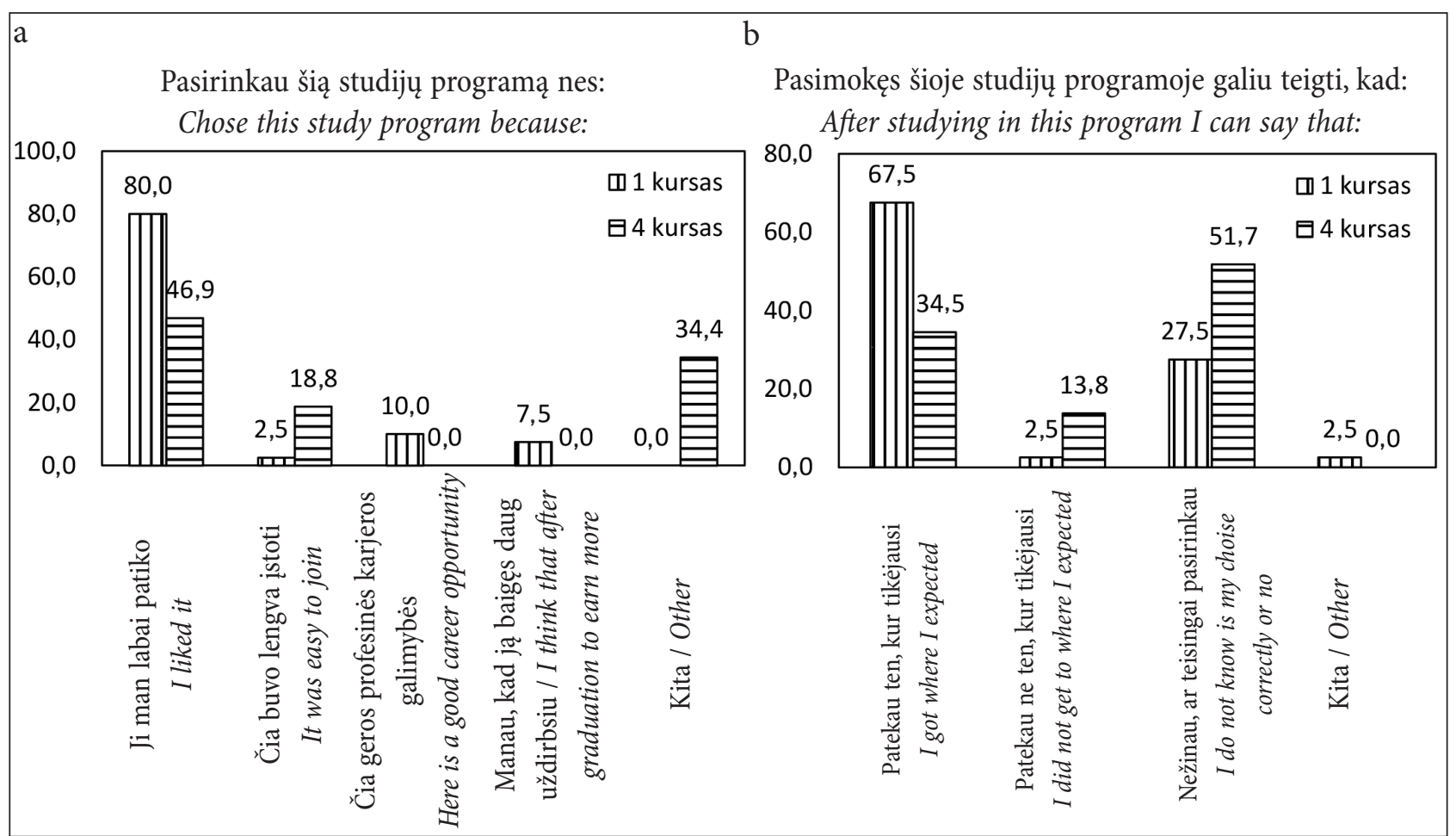

1 pav. Apklausose dalyvavusių studentų nuomonės pasiskirstymas (\%) atsakant ị klausimus apie meteorologijos ir hidrologijos studijų programos pasirinkimo motyvus (a) ir pasirinkimo teisingumą (b)

Fig. 1. Distribution of the surveyed students' opinions (\%) in response to questions about reasons of the choice of the meteorology and hydrology study programme (a) and choice correctness (b)

didesnè stojimo metu pažymejjusiųjų programą žemesniu nei trečiu numeriu dalis (tarp 4 kurso studentų tokių buvo $17,2 \%$, o tarp 1 kurso studentų - 7,5\%). Šią prielaidą iš dalies patvirtina ir tai, kad 34,4 \% ketvirtakursių, nurodydami pasirinkimo motyvus, nerado tinkamo standartinio atsakymo ir buvo priversti rinktis variantą „Kita“ (dažnas iš jų įrašè, kad stodamas negalvojo apie motyvus), o 18,8 \% rinkosi ją, nes čia buvo lengva ístoti (1 pav., a). Galimai analogiškos priežastys nulemè ir tai, kad daugiau nei pusè apklaustujų 4 kurse nurodè nežinantys, ar pasirinkdami šią studiju programą pasielgè teisingai, o nemenka dalis jų teigé, kad isstoję pateko ne ten, kur tikèjosi (1 pav., b). Kita vertus, tokie rezultatai pernelyg nestebina, nes praejus 6 ménesiams po studijų baigimo 59 \% Lietuvos aukštụjų mokyklų absolventų, paklausti, kokią specialybę rinktųsi jei studijuotų iš naujo, teigè, kad tos pačios specialybès nesirinktų (MOSTA, 2017).

Šiek tiek labiau skiriasi 1 kurso meteorologijos ir hidrologijos studentų nuomonė tais klausimais, kuriems išsiaiškinti būtina ilgesnè mokymosi patirtis. Atsakydami ị klausimą apie bendrą studijų programos lygi, 50,0 \% pirmakursių ịvertino ji kaip vidutinį, 47,5 \% kaip aukštą, o 2,5 \% kaip žemą (geografijos 1 kurso studentų atsakymai, atitinkamai, pasiskirste taip: 64,$1 ; 34,4$ ir 1,6\%). Nuomonių diferenciacija išryškèjo ir atsakant $\mathfrak{i}$ klausimus apie tai, kuo labiausiai nusivilta mokymosi metu bei dèl ko labiausiai padidètų noras mokytis: nors abiem atvejais daugiau kaip $50 \%$ respondentų rinkosi tą patį variantą (53,5 \% atsakiusiųjų teigé labiausiai nusivylę programos struktūra, o 53,7 \% mane, kad noras mokytis labiausiai padidètų jei jie žinotų, kad baigę mokslus gaus darbą pagal specialybę), kitus atsakymo variantus pasirinkusiųju dalis taip pat buvo nemenka ir siekè nuo keliolikos iki keliasdešimties procentu (2 pav.). Tarp 1 kurso geografu, palyginti su studijuojančiais meteorologiją ir hidrologiją, pasitaike daugiau tokių, kurių nuomone svarbiausias mokymosi motyvaciją skatinantis veiksnys yra galimybė baigus studijas dirbti pagal specialybę (62,5 \%). Kita vertus, lyginant su meteorologijos ir hidrologijos studentais, geografai 1 kurse buvo mažiau nusivylę studijomis: nors dažniausiai $(36,1 \%$ atvejų) tarp labiausiai nuvylusių dalykų ir vèl minèta studijų programos struktūra, net 24,6 \% jų rinkosi variantą „kita“, 


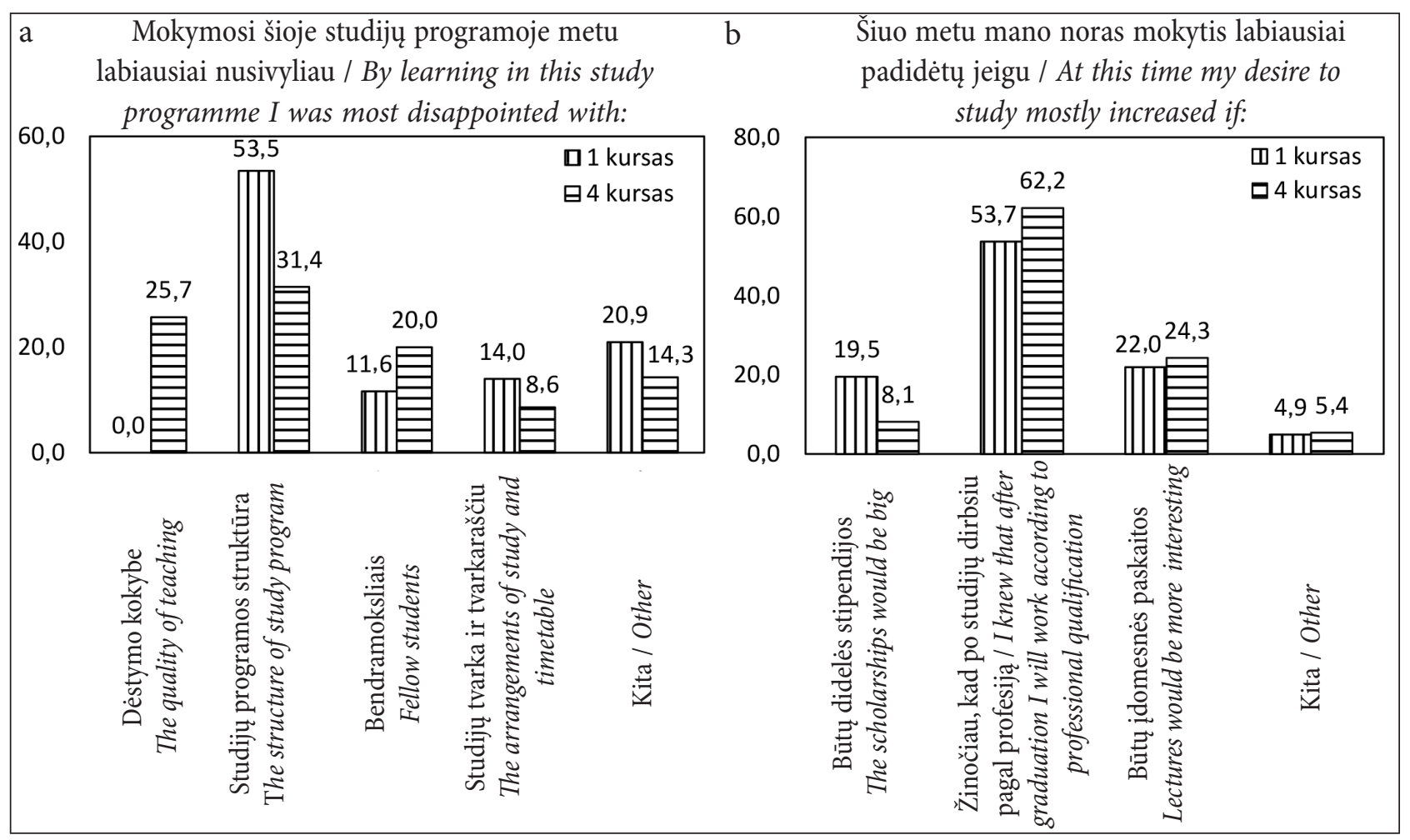

2 pav. Apklausose dalyvavusių studentų nuomonès pasiskirstymas (\%) atsakant $\mathfrak{i}$ klausimus apie veiksnius, kurie labiausiai mažina (a) ir didina (b) mokymosi motyvaciją meteorologijos ir hidrologijos studijų programoje

Fig. 2. Distribution of the surveyed students' opinions (\%) in response to questions about the factors that most decrease (a) and increase (b) the studying motivation of the meteorology and hydrology study programme

paprastai prirašydami, kad niekuo nenusivylè. Šie rodikliai simptomizuoja, kad meteorologijos ir hidrologijos pirmojo semestro studijų programa neatitinka studentų lūkesčių. Reikia pažymèti, kad nei vienas 1 kurso meteorologas ir hidrologas neišreiškè nusivylimo dėstymo kokybe, o 4 kurse nusivylimas programos struktūra gerokai padidèja (2 pav., a) - galimai todèl, kad spejama susidurti su kitais nuviliančiais dalykais, kurie 1 kurse dar nèra išryškejję - tad pirmajame semestre koreguotina visų pirma programos struktūra ir studijų organizavimo tvarka.

4 kurso meteorologijos ir hidrologijos studentų požiūris ì pasirinktos studijų programos lygi kiek pasikeitęs: dauguma (53,6 \%) vèl linkę îvardyti ji kaip vidutini, tačiau, palyginti su 1 kurso studentais, santykinai mažesnè dalis $(35,7 \%)$ laiko ji aukštu, o didesne (10,7 \%) žemu. Tad per laikotarpi nuo pirmojo iki septintojo semestro pabaigos padideja studijų programą prastai vertinančių studentų dalis. Spètina, kad tam įtakos turi smarkiai padidèjęs nusivylimas dèstymo kokybe (2 pav., a). Tačiau nederètų užmiršti, kad paskaitų dèstymo kokybès gerinimas (kartu su materialinès bazès gerinimu) nurodomas kaip 2-3 vietą pagal svarbą užimantis siūlymas visos Lietuvos bakalaurantams atsakant ị klausimą apie aukštosios mokyklos veiklos tobulinimo prioritetus (MOSTA, 2014), todèl teigti, kad meteorologijos ir hidrologijos studentai nusivylę studiju kokybe labiau nei kitų studijų programų atstovai, būtų neteisinga. Iki 4 kurso kiek pakinta ir studentus mokytis motyvuojančių veiksnių tarpusavio santykis: padaugejja studentų, kuriuos geriau mokytis labiausiai skatintu galimybe po studiju baigimo įsidarbinti pagal specialybę, santykinai šiek tiek didesnis tampa i̇domesnių paskaitų ar kitų veiksnių poveikis, tačiau ryškiai sumažèja studentų, kuriu motyvacija mokytis pageretu dèl didesnių stipendijų, skaičius (2 pav., b). Tai, kad stipendijos studentams nèra itin svarbios, patvirtina ir 1 kurso geografų apklausų rezultatai (stipendijas kaip galimą noro geriau mokytis motyvą minejjo $11,1 \%$ iš jų). Tuo tarpu studentu noras dirbti pagal specialybę nustatytas ir atliekant bendrus Lietuvos studentų nuomonès vertinimus: MOSTA (2017) duomenimis, atsakydami ị klausimą „Kalbant vien apie darbinę veiklą, 
ką labiausiai norètumète veikti pabaigę studijas? (1. Dirbti pagal specialybę. 2. Dirbti nebūtinai pagal specialybę.)“" studijų baigimo metu $67 \%$ aukštųjų mokyklų absolventų rinkosi 1 atsakymo variantą.

Pasisakydami apie studijų programos tobulinimo galimybes, 1 kurso meteorologai ir hidrologai net 70,0 \% atvejų nurodé, kad programos turinys pagerètų, jei joje būtų daugiau specialybės dalykų (3 pav., b). Analogišką nuomonę šiuo klausimu išreiške ir 68,3 \% pirmakursių geografų. Kad meteorologijos ir hidrologijos studentų pozicija šiuo klausimu nèra išskirtinè, įrodo ir bendri Lietuvos studentų apklausos rezultatai: $2014 \mathrm{~m}$. duomenimis, atsakydami ị klausimą apie galimus aukštosios mokyklos veiklos tobulinimo prioritetus, bakalaurantai tarp jų dažniausiai nurodydavo poreiki studijas labiau orientuoti i pasirengimą profesijai (MOSTA, 2014). Gana aiški pirmakursių nuomonè ir apie studijų trukmès korekcijas: 62,5\% meteorologų ir hidrologų bei 58,7 \% geografų mano, kad bakalauro studiju nereikia trumpinti. Studentų požiūris i galimus tvarkaraščio pakeiti- mus nėra toks vienareikšmis: $55 \%$ pirmakursių meteorologų ir hidrologų teigia, kad jiems būtų patogiau, jei užsièmimai truktų ilgiau, bet vyktų ne visomis darbo dienomis (tarp 1 kurso geografu tokių buvo $46,0 \%$ ), bet $32,5 \%$ jų (ir net $41,3 \%$ geografų) mané, kad geriau paskaitas organizuoti kasdien pirmoje dienos puseje. Tarp atsakymų $\mathfrak{i}$ klausimą apie galimus tvarkaraščio pakeitimus nepopuliariausias buvo siūlymas organizuoti didžiąją dalị paskaitų antroje dienos pusèje (už tai pasisakè $12,5 \%$ meteorologijos ir hidrologijos bei 12,7 \% geografijos studijų programos pirmakursių).

Idomu, kad 4 kurso meteorologijos ir hidrologijos studentų nuomone apie programos turinio pagerinimo galimybes, palyginti su pirmakursiu pozicija, beveik nepakito (3 pav., b). Absoliuti dauguma apklaustujjų vèl nurodè, kad programos turini labiausiai pagerintų didesnis tiesiogiai su specialybe susijusių dalykų skaičius. Kadangi tarp veiksnių, galinčių užtikrinti didesnę mokymosi motyvaciją, tiek 1, tiek 4 kurso studentai dažniausiai mini galimybę ateityje dirbti pagal profesiją (2 pav., b), vadinasi, planuojant programos ateiti pirmiausia

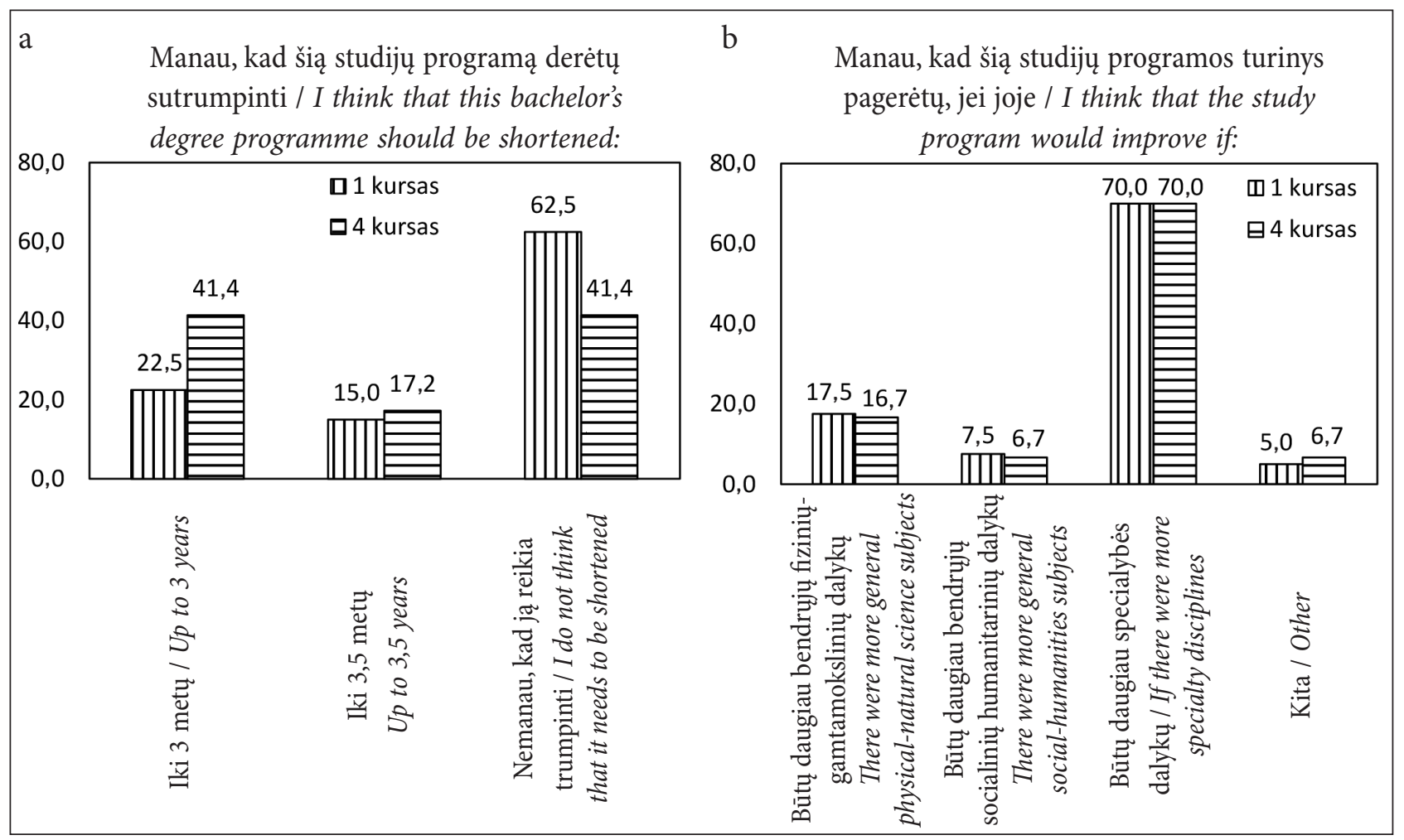

3 pav. Apklausose dalyvavusių studentų nuomonės pasiskirstymas (\%) atsakant $\mathfrak{1}$ klausimus apie galimas meteorologijos ir hidrologijos studijų programos trukmès (a) ir turinio (b) korekcijas

Fig. 3. Distribution of the surveyed students' opinions (\%) in response to questions about the potential duration (a) and content (b) corrections in the meteorology and hydrology study programme 
derètų skirti daugiau dèmesio specializuotiems ir labiau i praktiką orientuotiems dalykams. Studentų išsakytas noras mokytis daugiau specialybès dalyku gerai koreliuoja su bendromis Lietuvos tendencijomis: $2014 \mathrm{~m}$. duomenimis, praejus $6 \mathrm{mè-}$ nesiams po baigimo, tik $43 \%$ valstybinių universitetų absolventų teigè, kad aukštoji mokykla gerai paruošè juos darbo rinkai, kas dažniausiai taip pat siejama su universitetuose igytų profesiniu ịgūdžių stoka (MOSTA, 2017). Tai, kad galimybes pagerinti programos turinį dėstant daugiau bendrujų dalykų ¡žvelgia santykinai maža studentų dalis, nestebina, kadangi tarp fizinius ir technologijos mokslus Lietuvoje studijuojančių bakalaurantų yra itin mažai pritariančiųjų nuostatai, kad studijų metu turi būti dèstomi ne tik su studijuojama specialybe susiję dalykai, bet ir bendrieji dalykai (MOSTA, 2014). Net 87 \% fizinių mokslų bakalaurantų mano, kad studijos turi būti orientuotos ị praktinị specialistų rengimą (MOSTA, 2014). Ketvirtakursių nuomonè apie programos sutrumpinimo galimybes gerokai skiriasi nuo 1 kurso apklausų rezultatų ( 3 pav., a): 68,6\% studentų 4 kurse mano, kad bakalauro studijas derètų sutrumpinti (dažniausiai pasisakoma už studijų programos sutrumpinimą iki 3 metų). Prisiminus, kad didžioji dalis ketvirtakursių (skirtingai nuo besimokančių 1 kurse) teigia, jog pasimokę 7 semestrus nežino, ar teisingai pasirinko studijų programą (1 pav., b), galima spèti, kad noras ją trumpinti liudija, jog antrajame-septintajame semestruose dažniau susiduriama su nuviliančiais veiksniais. Kita vertus, menka ketvirtakursių motyvacija stojant ì šią studijų programą (kurią atspindi mažesnis pirmu numeriu prašymuose ją pažymejjusių studentų procentas ir mažesnè dalis istojusių čia todèl, kad ji labai patiko) liudija, kad apklausų laikotarpiu 4 kurso studentai buvo jau nuo pradžių prasčiau pasirengę studijoms nei tuo pačiu metu apklausti pirmakursiai. Nuo pirmojo iki septintojo semestro pabaigos taip pat smarkiai pakinta meteorologijos ir hidrologijos studentų požiūris ị tinkamiausią tvarkaraščio variantą: 48,3\% apklaustujų 4 kurse teigia, jog jiems patogiausia būtų lankyti užsièmimus pirmoje dienos pusèje; 27,6 \% jų norètų, kad paskaitos truktų ilgiau, bet nevyktų kasdien, 20,7 \% pageidauja, kad dauguma paskaitų vyktų antroje dienos pusèje, o 3,4 \% išsakè šiuo klausimu atskirą (dažniausiai neturinčią realaus igyvendinimo galimybių) nuomonę, pasirinkdami atsakymo variantą „kita“. Studentų po- žiūrio ị studijų tvarkaraštị pokyčiai 4 kurse, matyt, pirmiausiai sietini su didesne dirbančiu studentu dalimi: ankstesni tyrimai (MOSTA, 2014) rodo, kad dirbti apmokamą darbą Lietuvoje studentai paprastai pradeda 3-4 kurse. Be to, bendros aukštụjų mokyklų absolventų apklausos duomenimis, $77 \%$ jų, praejus 6 mènesiams po bakalauro studijų programos baigimo, teigia, kad studentui turi būti sudaromos sąlygos derinti darbą su studijomis (MOSTA, 2017).

Būtina pabrèžti, kad bendros apklaustujų studentų nuostatos, atsakant ì daugumą pateiktų klausimų, menkai priklauso nuo to, kokioje studiju programoje bei kelintame kurse jie studijuoja. Tai irodo ryšio tarp skirtinguose kursuose ir skirtingose studijų programose pasirinktų atsakymų variantu koreliacinè analizė. Koreliacijos koeficientas tarp 1 kurso meteorologų ir hidrologų bei 1 kurso geografų nuomonès procentinio pasiskirstymo visais klausimais lygus 0,95, kas liudija labai glaudu ryši tarp studentų pasirenkamų atsakymų variantų santykinès dalies. Koreliacija tarp 1 ir 4 kurso meteorologijos ir hidrologijos studentų atsakymų pasirinkimų kiek menkesnè $(r=0,82)$.

Mèginimai atsekti sąsajas tarp studentų atsakymų i skirtingus klausimus parodè, kad turimas duomenu kiekis kol kas nepakankamas siekiant gauti patikimus tokio tyrimo rezultatus. Dauguma atvejų daugiau kaip pusė apklaustųjų rinkosi identiškus atsakymus ị du klausimus tik tada, kai lyginti itin dažnai pasirenkami atsakymų variantai. Pavyzdžiui, dauguma 1 kurso meteorologų ir hidrologų teigia, kad pasirinko šią studijų programą dèl to, kad ji jiems labai patiko, todèl ypač didelis procentas apklaustųjų, nurodydami šią programos pasirinkimo priežastį, turi vienodą nuomonę ir kitais klausimais $(60,0 \%$ taip pat teigia, kad stodami rinkosi šią programą pirmu numeriu, 60,0 \% mano, kad pateko ten, kur tikejosi, 60,0 \% apie ją sužinojo internete, 55,0 \% mano, jog jų noras mokytis labiausiai padidètų, jei programoje būtu daugiau specialybès dalyku, o 50,0 \% nemano, kad studijas reiketuc trumpinti). Be to, 53,0 \% pirmakursių ne tik stojimo metu pasirinko ją pirmu numeriu, bet ir mano šiuo metu galintys teigti, kad pateko ten, kur ir tikèjosi, o 50,0 \% pasirinko ją pirmu numeriu ir sužinojo apie programą internete. 55,0 \% sužinojo apie programą internete ir šiuo metu mano, kad pateko ten, kur ir tikejosi. Sąsajas tarp šių atsakymų nesunku paaiškinti (tie, kam 
studijų programa patiko prieš stojant, dažniau renkasi ją pirmu numeriu, mano patekę ten, kur tikejosi ir labiau domisi su specialybe susijusiais dalykais). Didelis internetu apie studiju programą sužinojusiųjų procentas taip pat nestebina, nes internetas buvo svarbiausias informacijos šiuo klausimu šaltinis net 72,3 \% apklaustų pirmakursių.

İdomesnius studentų požiūrio aspektus atskleidžia ryšiai tarp rečiau pasirenkamų atsakymų variantų. Pavyzdžiui, dauguma pirmakursių, kurie stodami pažymèjo šią programą žemesniu nei pirmu numeriu, teigia, kad stodami tikejosi, jog mokytis čia bus lengviau (šiuos du atsakymų variantus pasirinkusiujuc dalis sudaro $20,0 \%$ nuo bendro apklaustụjų skaičiaus). 30,0 \% pirmakursių ne tik nurodè manantys, kad bendras studiju programos lygis yra aukštas, bet ir teigè, kad prieš įstodami tikejjosi, jog mokytis joje bus lengviau. Tokios sąsajos rodo, kad programos lygio vertinimas studento akimis bei su ja siejami lūkesčiai labai priklauso nuo stojančiojo pasirengimo ir nusiteikimo studijuoti. Šie duomenys galimai atspindi ir tai, kad nemenka dalis studentų, pasirinkusių meteorologijos ir hidrologijos studijas, ateina studijuoti nepakankamai pasirengę ir jau pirmajame semestre (kur didžiąją dali dalykų sudaro bendrosios bazinès disciplinos) sunkiai susitvarko su mokymosi užduotimis.

4 kurso studentų apklausose didžiausias identiškų nuomonių procentas vèl pastebėtas tais atvejais, kai atsakant ị tam tikrą klausimą išreikšta vieninga vyraujanti nuomonè. Pavyzdžiui, meteorologijos ir hidrologijos ketvirtakursiai ypač dažnai teigè, kad jų noras mokytis labiausiai padidètų, jei jie žinotų, kad baigę mokslus dirbs pagal profesiją. Todèl nestebina, kad daugiau nei pusè visu respondentu rinkosi ne tik ši teiginí, bet ir išsake poziciją, kad programos turinys pagerètų, jei joje būtų daugiau specialybès dalykų (62,0\%), sužinojo apie studijų programą internete $(55,0 \%)$, stodami žymejo ją pirmu numeriu (52,0 \%). Svarbu pabrèžti, kad 48,0 \% 4 kurso studentų tuo pačiu metu teigia, kad programos lygis nera aukštas (ivertindami ji kaip vidutinị arba žemą) ir mano, kad jos turinys pagerètų, jei būtų dèstoma daugiau specialybès dalykų. Tai dar kartą įrodo, kad ateityje derètų stengtis programoje didinti tiesiogiai su specialybe susijusiu dalyku santykinę dali. Dalis 4 kurso meteorologų ir hidrologų apklausų rezultatų išryškina gana savitus studentų požiūrio aspektus. Pavyzdžiui, 45,0 \% jų teigia šiuo metu manantys, kad stodami čia „pataikè ne ten, kur norejjo“ arba „nežino, ar teisingai pasirinko“ ir tuo pačiu metu vertina programos lygi kaip vidutini arba žemą, o 41,0 \% ne tik abejoja savo pasirinkimo teisingumu, bet ir įsitikinę, kad studijas derètu sutrumpinti (iki 3 ar 3,5 metų). Nors esant nedideliam apklaustųu skaičiui 4 kurse šie skaičiai negali būti traktuojami kaip patikimą statistini ryši liudijantys rodikliai, jie atskleidžia, kad nemaža dalis paskutinio kurso studentu yra nusivylę studijomis ir siekia tik kuo greičiau gauti diplomą (nebelaikydami prioritetu studijų metu ịgyjamų ịgūdžių).

\section{APIBENDRINIMAS}

Apklaustų studentų nuomonè apie meteorologijos ir hidrologijos studijų programą gana vieninga. Tai ypač būdinga pirmakursiams: daugiau nei $50 \%$ apklaustuju rinkosi tą patị atsakymo variantą atsakydami ị 10 iš 11 anketoje pateiktų klausimų. Nors kai kuriais klausimais studentų nuomonè nuo pirmojo iki septintojo semestro pabaigos gerokai pasikeičia, tarp 1 ir 4 kurso studentų pasirinktu atsakymu variantu santykinès dalies egzistuoja gana glaudus ryšys (koreliacijos koeficientas $r=0,82$ ). Daugeliu klausimų vyraujanti meteorologijos ir hidrologijos studentų nuomonè sutampa su MOSTA vykdytose bendrose Lietuvos aukštųjų mokyklų bakalaurantų apklausose išryškejjusiomis tendencijomis.

Vienareikšmè pozicija studentams labiausiai būdinga charakterizuojant programos pasirinkimo aplinkybes. Identiškas požiūris it klausimus šia tema ypač dažnas tarp pirmakursių: $80 \%$ ju teigia, kad pasirinko studiju programą, nes ji labai patiko; $73 \%$ apie ją sužinojo internete; $68 \%$ pildydami prašymus pažymejjo ją pirmu numeriu; $68 \%$ mano galintys teigti, kad įstoję „pateko ten, kur tikejosi“. 4 kurso studentų nuomonè dauguma šių klausimų panaši, kiek ryškiau skiriasi jų požiūris i programos pasirinkimo motyvus ir savo vietos joje suvokimą (tik $47 \%$ nurodo, kad programą rinkosi dèl to, jog ji labai patiko; bet $52 \%$ teigia nežinantys, ar pasirinkdami šią studijų programą pasielgè teisingai, o $14 \%$ ịsitikinę, kad ịstoję pateko ne ten, kur tikejjosi). Priežastis gali būti žymiai didesnè apklaustuju ketvirtakursių, stojimo metu prašyme žymèjusių programą žemesniu nei trečiu numeriu, dalis (galimai jie buvo prasčiau pasirengę studijoms). 
Studentų požiūris į studijų programos lygi ir mokymąsi skatinančius veiksnius labiau diferencijuotas. $50 \%$ pirmakursių vertino programos lygi kaip vidutiní, $47 \%$ kaip aukštą, o $3 \%$ kaip žemą. 4 kurso studentų požiūris ị programos lygi kiek pakitęs: nors dauguma (54\%) vèl ịvardija ji kaip vidutinį, gerokai mažesnè dalis (36 \%) laiko ji aukštu, o didesnè (11\%) žemu. Tad per laikotarpi nuo pirmojo iki septintojo semestro pabaigos padidejja studijų programą prastai vertinančių studentų dalis (galimai tai susiję ir su padidejusiu nusivylimu dèstymo kokybe). Iki 4 kurso pakinta ir studentus mokytis motyvuojančių veiksnių tarpusavio santykis: padaugejja studentų, kuriuos geriau mokytis labiausiai skatintų galimybe po studijų baigimo įsidarbinti pagal specialybę, santykinai didesnis tampa įdomesnių paskaitu ar kitokių veiksnių poveikis ir labai sumažèja studentų, kurių motyvacija mokytis pagerètų dèl didesnių stipendijų, skaičius.

Apibūdindami potencialias studijų programos koregavimo galimybes 1 ir 4 kurso studentai buvo vieningi: $70 \%$ atvejų nurodé, kad programos turinys pagerètų, jei joje būtų daugiau specialybès dalykų. Tai sutampa su MOSTA tyrimuose išryškinta bendra Lietuvos bakalaurantų nuostata, jog esminis aukštosios mokyklos veiklos tobulinimo prioritetas yra labiau orientuoti studijas ị pasirengimą profesijai. 1 ir 4 kurso studentų nuomonè apie galimas studijų trukmès korekcijas ryškiai skiriasi: $63 \%$ pirmakursių mano, kad bakalauro studiju trumpinti nereikia, o 69 \% ketvirtakursių nuomone, jas derètų sutrumpinti (dažniausiai pasisakoma už sutrumpinimą iki 3 metų). Toks požiūrio pokytis (atsižvelgiant ị tai, kad dauguma studentų 4 kurse teigia, jog nežino, ar teisingai pasirinko studijų programą) leidžia spèti, kad antrajame-septintajame semestruose dažniau susiduriama su nuviliančiais veiksniais. Apklaustųjų požiūris ì galimus tvarkaraščio pakeitimus labai nevienareikšmis ir neleidžia daryti išvadų apie studentams labiausiai priimtiną jo variantą.

Mèginimai atsekti sąsajas tarp studentu atsakymų i skirtingus klausimus parodé, kad duomenų kiekis nèra pakankamas siekiant gauti patikimus tokio tyrimo rezultatus. Daugiau kaip pusès apklaustuju nuomone dviem klausimais paprastai būdavo identiška tik lyginant dažniausiai pasirinktų atsakymų variantus. Dėmesys atkreiptinas i sąsajas, kurios atskleidžia ryšius tarp rečiau pa- sirenkamų atsakymų. Daug pirmakursių ne tik nurodo, kad prieš stodami tikejosi, jog mokytis bus lengviau, bet ir mano, kad bendras programos lygis yra aukštas (30 \%) arba žymejjo ją žemesniu nei pirmu numeriu (20\%), vadinasi, tai, kaip studentai vertina programą ir kokius lūkesčius su ja sieja, priklauso nuo stojančiojo pasirengimo ir nusiteikimo. $45 \%$ ketvirtakursių teigia, kad stodami „pataikè ne ten, kur norejo“ arba „nežino, ar teisingai pasirinko“ ir tuo pačiu metu vertina programos lygi kaip vidutinị arba žemą, o $41 \%$ ne tik abejoja savo pasirinkimo teisingumu, bet ir mano, kad studijas derètų sutrumpinti, kas liudija, jog nemaža dalis 4 kurso studentų yra nusivylę studijomis ir labiau siekia gauti diplomą, nei ịgyti naujų ịgūdžių.

Studentu atsakymai i pateiktus klausimus rodo, kad tiek stojant, tiek mokantis meteorologijos ir hidrologijos studiju programoje jiems itin svarbus domejjimasis profesiniais klausimais. Svarbiausiu žinių šaltiniu renkantis studijas laikomas internetas. Rezultatai leidžia teigti, kad esminiai šios studijų programos tobulinimo prioritetai yra: a) programos orientavimas ì geresni studentų profesini parengimą, taip padidinant ir absolventų ịsidarbinimo pagal specialybę galimybes; b) platesnis programos pristatymas interneto erdveje, mėginant sudominti ja daugiau aukšto lygio žiniomis ir entuziazmu pasižyminčių stojančiųjų.

Gauta 20170328

Priimta 20170419

\section{Literatūra}

1. Čèsnaitė B. 2002. Studijų kokybė: aukštųjų mokyklų absolventų vertinimai. Filosofija. Sociologija. 13(3): 27-34.

2. Gudaitytė D., Jucevičienè P. 2000. Elitinio aukštojo mokslo tapimo masiniu proceso esmé: paradigma ir charakteristikos. Socialiniai mokslai. 3(24): 112-122.

3. Jezerskytė E., Janiūnaitė B. 2010. Universiteto dèstytojo inovacinès veiklos turinys: teorinès ir empirinès įžvalgos. Jaunųu mokslininku darbai. 1(26): 69-76.

4. Kanopienè V., Tureikytė D. 2001. Studentų požiūris ì studijas priklausomai nuo lyties. Lytiškumas ir švietimas: pažiūrų, stereotipu ir 
ugdymo turinio tyrimai. Vilnius: Moterų informacijos centras. 108-123.

5. Kanopienè V., Tureikytė D. 2002. Vilniaus universiteto studentų požiūris ì studijas. Filosofija. Sociologija. 13(1): 68-76.

6. Lepaitè D. 2003. Kompetencija pletojančiu studiju programu lygio nustatymo metodologija. Kaunas: Technologija. 193 p.

7. MOSTA. 2014. Studiju kokybe Lietuvoje: suinteresuotu šaliu požiūris. http://mosta.lt/images/leidiniai/Studiju_kokybe_Lietuvoje_suinteresuotu_saliu_poziuris.pdf (paskutinị kartą žiūrèta 2017-03-07).

8. MOSTA. 2017. Bandomojo longitudinio absolventu karjeros stebesenos tyrimo ataskaita. http://www.mosta.lt/images/leidiniai/absolventu_karjeros_stebesenos_tyrimo_ataskaita. pdf (paskutinị kartą žiūrèta 2017-03-21).

9. Pruskus V., Palevičiūtè O., Kocai E. 2015. Studentų studijų kokybès vertinimas ir jų lūkesčiai (LEU atvejis). Santalka. 23(1): 14-25.

10. Rosinaitė V. 2008. Lietuvos aukštụjų mokyklų studentų career development kompetencijos: subjektyvus jų įsisavinimo lygio ir ugdymo poreikio ịvertinimas. Filosofija. Sociologija. 19(4): 62-71.

11. Savickienè I., Pukelis K. 2004. Studijų kokybès vertinimas instituciniu lygmeniu: dimensijos, standartai ir kriterijai. Aukštojo mokslo kokybe. 1: 26-37.

12. Savickienè I. 2005. Universitetinių studijų kokybès vertinimo sistemos parametrai. Aukštojo mokslo kokybe. 2: 72-83.

13. Sirtautienè, D. 2006. Studijų universitete kokybès vertinimo aspektai: studentų požiūrio tyrimas. Pedagogika. 83: 117-121.

14. Tijūnèlienė O. 2012. Studentų nuomonių apie dėstytoją fenomenologinis tyrimas. Tiltai. 70(4): 105-121.

15. Valiuškevičiūtė A., Druskytè R., Mikutavičienè I. 2004. Universitetinių studijų kokybès vertinimas: akademinès bendruomenès požiūris. Aukštojo mokslo kokybè. 1: 38-59.

16. Vilniaus universiteto Kokybès vadybos centras. 2017. Apklausu apie studiju kokybę rezultatai. http://www.kvc.cr.vu.lt/site/?q=node/68 (paskutinị kartą žiūrèta 2017-03-06).
Gintaras Valiuškevičius

\section{STUDENTS' OPINION ABOUT THE VILNIUS UNIVERSITY METEOROLOGY AND HYDROLOGY BACHELOR'S DEGREE PROGRAMME (2014-2016 SURVEY)}

\section{Summary}

The article analysed results of students' anonymous survey about Vilnius University meteorology and hydrology bachelor study programme. The survey was conducted in $2014-2016$ by distributing questionnaires among 1-year and 4-year students. The students' opinion about the meteorology and hydrology study programme is quite uniform. This is particularly true for the first-year students: more than $50 \%$ of the respondents chose the same answer option by answering 10 of 11 questions. In many questions the prevailing opinion of meteorology and hydrology students coincides with the tendencies which were identified in the joint Lithuanian higher schools undergraduate students' survey.

The most unambiguous were students' answers about the circumstance of programme selection. Similar approach to questions in this topic was especially frequent among freshmen: $80 \%$ of them said that they chose the study programme because they liked it, $73 \%$ learned about it on the Internet, $68 \%$ marked it in applications as number 1 , and $68 \%$ could say after admission "I got where I expected". 4-year students' opinion about most of these issues was similar. Significantly different was 4-year students' approach to programme selection motives and perception of their positions in this programme (only $47 \%$ indicated that they chose the programme because they liked it, 52\% said they did not know if they chose the right study programme, and $14 \%$ said "I did not get to where I expected").

The students' approach to the study programme level is more different. 50\% of freshmen rated the programme level as ordinary, $47 \%$ as high, and $3 \%$ as low. Most 4 -year students (54\%) also ranked the programme level as ordinary, but a significantly smaller proportion (36\%) evaluated it as high, and a still smaller proportion (11\%) as low.

In describing the potential correction of study programme, the 1-year and 4-year students in $70 \%$ of cases indicated that the content of the programme would improve if there were more specialty subjects. This is consistent with the overall opinion of 
Lithuanian undergraduate students that the essential higher school improvement priority is the greater focus on professional readiness in studies. 1-year and 4-year students' opinion about the corrections of study duration differed significantly: $63 \%$ of freshmen believed that there was no need to shorten undergraduate studies and $69 \%$ of 4 -year students believed that they should be shortened (most students proposed reduction of up to 3 years).

Responses of students indicate that professional issues are important for them. The most important source of knowledge about the studies is considered to be the Internet. The substantial priorities of programme improvement are: a) orientation of the programme towards better vocational training of students and $b$ ) wider presentation of the programme on web space.

Keywords: higher education, meteorology and hydrology, Vilnius University, student survey, approach to learning 